\title{
The Implementation of the Scientific Approach: Reveal the Degree of Scientific Approach Application in Biology Instruction That Had Been Carried Out
}

\author{
Uswatun Hasanah ${ }^{1, *}$ Slamet Suyanto ${ }^{2}$ \\ ${ }^{1}$ Master of Biology Education, Faculty of Mathematics and Natural Sciences, Universitas Negeri Yogyakarta, \\ Indonesia \\ ${ }^{2}$ Department of Biology Education, Faculty of Mathematics and Natural Sciences, Universitas Negeri \\ Yogyakarta, Indonesia \\ *Corresponding author. Email: uswatunhasanah.2018@student.uny.ac.id
}

\begin{abstract}
In 2013, the Indonesian government implemented Curriculum 2013 (C-13). C-13 requires applying a scientific approach in the learning process. This research aimed to describe the implementation of the scientific approach and see how application of the scientific approach in learning biology. The research sample consisted of 158 students from three senior high schools in Martapura, South Sumatra. The instrument used in this study was a questionnaire that was distributed to respondents via Google form. The data were subsequently analysed with descriptive quantitative. The result of the percentage of student activities in the biology learning process is a good category in conducting the scientific approach is $66.73 \%$. The results of percentage of the level of ease and difficulty in implementing the scientific approach were as follows: (1) Observing (M1) was 76.58\%, (2) Asking questions (M2) was 57\%, (3) Doing experiments (M3) was 62.6\%, (4) Reasoning (M4) was 30.3\%, and (5) Communicating (M5) was $21.5 \%$. Therefore, it's was concluded that based on the various biological problems that arise, it is known that the application of the scientific approach has very important to improving the soft skills and hard skills of students in learning biology.
\end{abstract}

Keywords: Scientific approach, Biology learning, Student high school

\section{INTRODUCTION}

The 2013 curriculum, which was inaugurated in Indonesia starting in 2013, still has crucial problems in the implementation. Some of the influencing aspects include the existence of comparisons of learning cases in each region. Some schools in the province of South Sumatra have not been able to practice the 2013 curriculum. there are aspects of the cause are the teaching staff who have not implementation optimally with the facilities have not been optimal. The 2013 curriculum concern the standard of the primary and secondary learning process reports that in the learning must apply a scientific approach. In the learning process, the scientific approach has not implementation optimally in the classroom. That is evidence from several research studies that have trying to be associated with learning innovations to improve student abilities based on student learning outcomes.

The results of the PISA test and survey in 2015 involving 540,000 students got a score of 403, although it has increased compared to the PISA results in 2012, which was a score of 382, but when compared to the OECD average it is still low. Based on the results of TIMMS in 2015, the ability of students to answer high-level questions was only $4 \%$. Based on these results it can be assumed that the quality of education in Indonesia especially in the field of science, is far behind compared to other countries.

The quality of student learning outcomes is certain influenced by the success of the learning process applied. Some factors influence the quality of learning outcomes of students. in a fact that a learning process 
of biology is still teacher-centered and not many are oriented towards habituation and increasing highorder thinking skills (critical thinking), educators focus on solving material rather than applying and developing learning methods [8], applying learning models that are less varied and interesting, students are not trying usually to apply knowledge in solving problems in everyday life [3], learning is still applying the concept of memorization [2], insufficiency of facilities and infrastructure, including media and teaching materials [10], and the learning process is still teacher-centered, causing students to be less active in learning [8], [9].

The scientific approach is an approach pedagogical use of appropriate steps with the scientific method [11]. A scientific approach is an approach that prioritizes increasing the dimensions of observation, reason, invention, oversight approval, and an explanation of one to the truth. This approach gives a chance to improve the ability of students to make observations, ask questions, reason, and communicate knowledge obtained from the learning process. Through stages approach scientific, teacher is guided by gradually to organize and perform research. The learning process with a scientific approach is cognitive, psychomotor, and affective to form the participant students were productive, creative, innovative, and effective through the strengthening of attitudes, skills, and integrated knowledge [5], That is, the scientific approach aims to build critical thinking skills and students' analytical thinking based on the scientific process during learning. By applying a scientific approach, students are encouraged to solve the problems they question self. It is believed that a scientific approach can be used to help them learn many things [15].

The stages of a scientific approach consist of observing, questioning, experimenting, processing data or information followed by analysing; associating; and concluding, presenting data or information (communicating), and networking. The stages can be summarized in the fifth stages, namely observing, asking, trying, processing data, and communicating.

Viewing is an activity to identify the characteristics of a particular object with various sensing devices students carefully, using relevant facts, use equipment or materials as supporters to observe objects to collect data or information and is done by using five kinds of senses. In this case, the students prepare learning tools in the form of learning media such as videos, figures, miniatures, impressions, or original objects.
Asking is an activity to ask questions about the information that students do not understand that comes from something observed or question to get additional information about something that is observing.

Collecting information activity for students do experiments, read sources other than textbooks, observe objects/events/activities, interviews with the sourcing. In this learning step, each student can be requiring to try to practice what happened.

Associating is an activity where students can connect what is learning with what is in everyday life. Associating the activities has two stages, first, processing information that has collecting from the activity or learning resource; second, processing information collecting in-depth to information processing that seeks solutions from various sources that differ with conflicting opinions.

The results of the study before reveal right that the applied approach is scientific in the learning process of biology can improve learning outcomes of students like critical thinking skill, analytical thinking skills, science process skills, scientific attitude, literati science, and so forth. The implementation would have to consider several things to get the results of learning desired. Among them are doing the best possible lesson planning and as much as possible by paying attention to several things such as school situations and conditions, school facilities, time allocation, and most importantly the characteristics of students. Considering the level of intellectual development, motor skills, and attitudes of students, teaching materials, competencies, and learning experiences carried out by students with teacher guidance. In general, teaching and learning activities in Biology only emphasize aspects of conceptual mastery with traditional teaching models. Teachers only use the lecture, note-taking, and assignment methods, while students are not allowed to practice to develop logical, creative, inspirational, and innovative thinking skills [12].

Also, the application of a scientific approach to learning biology has found some very crucial problems as previously described. Biology lessons attempt to equip students with various abilities on how to "know" in the form of product an aspect, and how to "do" which are aspects of processes in everyday life. Biology learning is expected to carry out learning objectives based on competency standards and basically, competencies to form a positive attitude and the ability to collaborate to develop analytical, inductive, deductive thinking skills using the concepts and principles of Biology [14]. 
Each stages of scientific approach have advantages and roles of each for improving ability teacher either soft skills and hard skills of teacher. One of the results of research conducted [16] that applying the scientific approach in biology learning can improve cognitive learning outcomes and science process skills students with the results of the study stated that enhancing the learning outcomes of cognitive by $20 \%$ and science skills for $9.25 \%$.

Based on the results of the initial survey conducted in three SMA Martapura South Sumatra, there are 98\% of the students still not aware of the approach to science. But if some of the stages contained in the scientific approach can explain and students will understand activities such as observing, discussion, experimentation, question and answer, and experiment. In theory, the application of a scientific approach stages can indeed produce character graduates. That's all that can be realize if on a practicing good and maximum efforts to make.

Based on various things in the above categories, although the knowledge of student learning outcomes in the city of Martapura is still in the low category. So, in this study, we want to see and analyze the process of implementing the scientific approach, to reveal the degree of application of the scientific approach in biology, including students' understanding of the scientific approach, and student responses to learning. application of a scientific approach in the learning process of biology at SMA Negeri Martapura, South Sumatera.

\section{RESEARCH METHOD}

This research is a quantitative descriptive study. The research sample consisted of 158 students from three schools in Martapura, South Sumatra. The research instrument used was in the form of a questionnaire that was distributed to students via Google form. The data analysis technique used percentage tabulation from Google form.

\section{RESULT AND DISCUSSION}

\subsection{Application of A Scientific Approach in Biology Learning}

The results of this study indicate that the process of applying a scientific approach in biology learning is in a good category, although several things must be improved and perfected in its implementation. Students also give positive responses to learning activities by applying a scientific approach. The results of questionnaires related to the activities of students in the learning process can be seen in table 1 .

Table 1. Student activities in the biology learning process

\begin{tabular}{|c|l|c|c|}
\hline \multirow{2}{*}{ No. Indicators } & \multicolumn{1}{|c|}{ Yumber of respondents' answers (\%) } \\
\cline { 3 - 4 } & & \multicolumn{1}{|c|}{ No } \\
\hline 1 & Preparation before starting learning & 59.1 & 40.9 \\
\hline 2 & Understand the design of the learning process & 67.05 & 32.95 \\
\hline 3 & Pay attention to what the teacher says & 69.92 & 30.08 \\
\hline 4 & Work on student worksheet from the teacher & 79.1 & 20.9 \\
\hline 5 & $\begin{array}{l}\text { Discuss problems encountered in teaching and learning } \\
\text { activities }\end{array}$ & 61.83 & 38.17 \\
\hline 6 & Carry out an investigation / data collection & 80.1 & 31.63 \\
\hline 7 & Ask questions related to material that don't understand & 68.37 & 40.32 \\
\hline 8 & Make a joint decision from all the answers that are & 59.68 & 44.6 \\
\hline 9 & considered the most correct & & 33.27 \\
\hline
\end{tabular}

According to the Table 1. above shows that the average figure activity undertook students is $66.73 \%$ with the category of moderate, suggesting that the activity of students in the process of learning by applying a scientific approach done pretty well. Meanwhile, the percentage of $33.27 \%$ indicates that students have not carried out activities optimally in learning. Activities students before teachers delivering 
course material are to know and understand the purpose of learning, to understand a little figure of the material to be studied, understood models and methods to be applied in the learning process and has an interest and high motivation to learn. Activities carried out by students when the teacher begins to deliver the material is to pay attention and listen well and answer questions given by the teacher. Activities carried out by students in the learning process are analysing the problems presented by the teacher in the form of LKPD, conducting good group discussions, collecting and analysing data, drawing conclusions, and communicating in front of the class. For observation or practicum (experiment) activities, students feel excited and active, students can make observations and carry out data collection and data analysis well even though in some activity's teacher guidance is still needed.

\subsection{The Level of Ease and Difficulty in Implementing the Scientific Approach in Learning Biology}

The results of the student questionnaire calculations related to the level of difficulty and ease of activity in implementing the scientific approach stages include observing activities as shown in Figure 1 , questioning stages in figures 2 , the stages of collecting information or trying in figures 3 , the stages of reasoning activities in figures 4, and stages communicating in figures 5 .

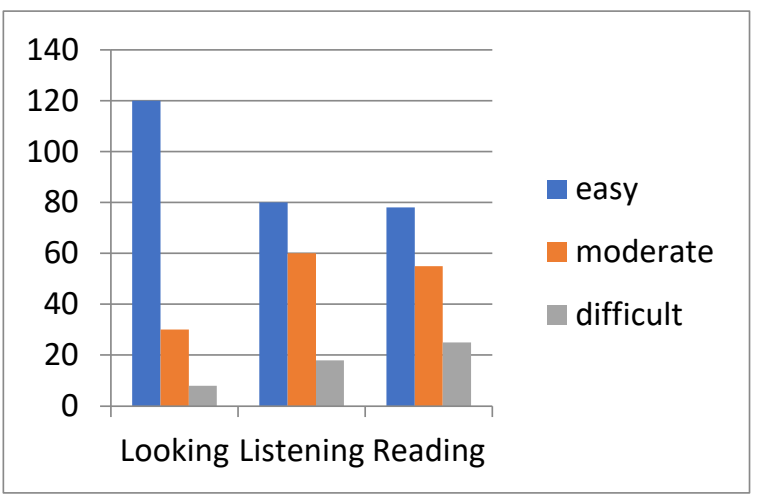

Figure 1 The level of ease and difficulty in implementing observing activities in the stages of a scientific approach in the biology learning process

Based on the results shown in Figure 1, viewing activities are the easy activity to do according to 120 students 'opinions reading activities are the most difficult activities to do because students' reading literacy skills fall into the low category. Students will be happier if they get information by seeing what the teacher explains through PowerPoint media rather than reading books directly that can cause boredom and lack of attention.

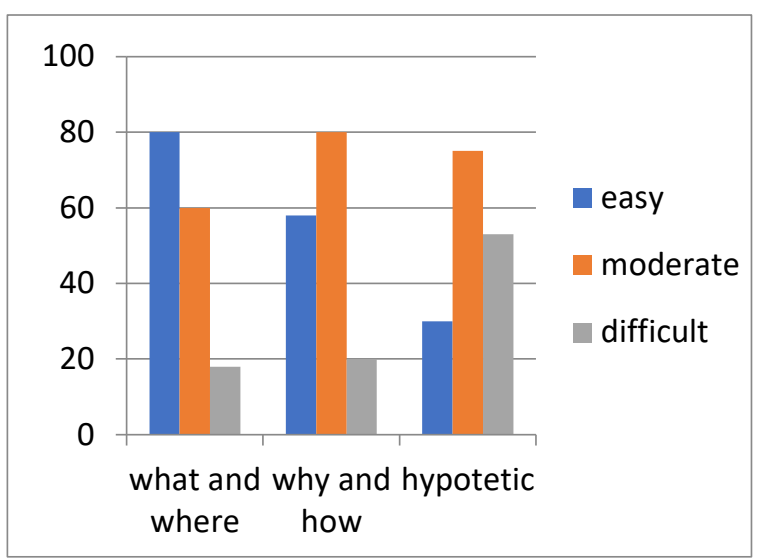

Figures 2 The level of ease and difficulty in implementing questioning activities in the stages of a scientific approach in the biology learning process

The figure above shows that in the questioning activity, students would ask questions like "what" and "where" more often and easy to do than asking hypothetical type questions. That's also just because of the low critical thinking skills of students to understand and learn a subject. Meanwhile, the "why" and "how" questions are including in the medium category.

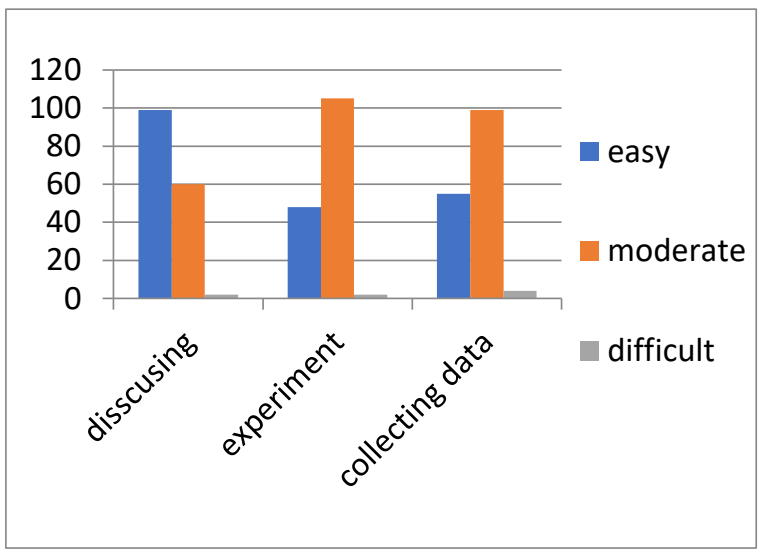

Figures 3 The level of ease and difficulty of implementing information gathering/trying activities in the stages of a scientific approach in the biology learning process.

The figure above shows that the easy activity to do in gathering information is when students are asking to carry out discussions between groups to solve a problem. The purpose of an experiment is to determine whether observations agree with or conflict with the predictions derived from a hypothesis [7]. Experimental activities are including in activities that 
have a moderate level to do. Meanwhile, the most difficult activities to do is when students are asking to collect data through a literature study. That is also still influenced by the lack of reading literacy skills of students and the limited learning resources available.

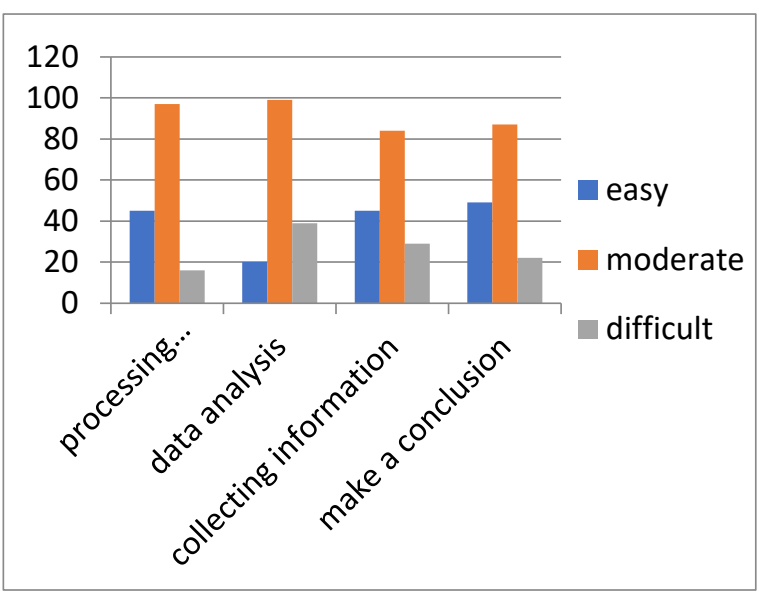

Figures 4 The level of ease and difficulty in implementing reasoning activities in the stages of a scientific approach in the biology learning process

The figure above shows that in the application of reasoning stages, information-processing activities according to 45 students are included in the easy category, 97 students choose the medium category, and 16 students choose the difficult category. In data analysis activities, the number of students who chose the easy, medium, and difficult categories was 20, 99, and 39 students, respectively. In gathering information, the number of students who chose the easy, medium, and difficult categories was 45, 84, and 29 students, respectively. As for the activity of making conclusions, the number of students who chose the easy, medium, and difficult categories was 49,87 , and 22 students, respectively.

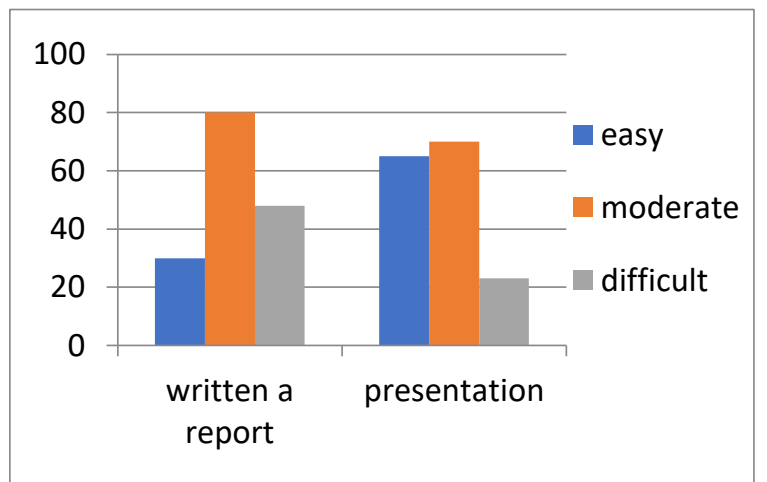

Figures 5 The level of ease and difficulty in implementing communicating activities in the stages of a scientific approach in the biology learning process
The figure above shows that in the communicating stages, activities presentation assessed more easily by number 65 students choose the category, 70 students choose the medium levels, and 23 students choose a level difficult. As for the activity of making reports, as many as 30 students chose the low category, 80 students chose the medium level, and 48 students chose the level of activities that were difficult to do.

The application of the scientific approach in the learning process of biology always strives so that it can be carried out optimally by the students, although other factors can affect the less more than optimal implementation of the scientific approach. As described in table 1 . shows that the application of the scientific approach is in a good category. The willingness of students to follow the learning process by trying to execute each step of the scientific approach properly.

Each implementation of the scientific approach stages in learning has different levels, starting from activities that students think are easy to do, such as viewing activities, conducting discussions, and presenting the results of discussions in front of the class with more than 60 students choosing that category. That shows that students are willing to be actively involved in the learning process. Whereas for activities that are difficult to do according to students are reading activities, asking questions that are hypothetical which means that students still have difficulty doing high-order thinking skills (HOTS) [14], the "Why" and "How" part of higher-level thinking as well as critical thinking skills [1], [4], as well as collecting and analysing data, as well as making reports on discussions or observations.

\subsection{The Importance of Applying A Scientific Approach in Learning Biology}

Based on the results of the student questionnaire analysis, following the nature of learning biology, it is so important to choose a scientific approach as an alternative in learning to improve the soft skills and hard skills of students. The activity of observing helps students to become human beings who are more sensitive and conscientious and are accustomed to using various senses in response to a problem. Questioning activities can help students to increase curiosity, think critically, and think analytically. The competencies that want to be developed from this questioning activity are developing creativity, curiosity, the ability to formulate questions to form critical thoughts that are necessary for living smart and lifelong learning. In this step, a successful learning atmosphere is the occurrence of active communication 
in the discussion of subject matter [12]. The activity of gathering information can help students improve various kinds of literacy and help develop students' scientific attitudes. Reasoning activities help students to improve critical thinking skills, analytical thinking, and various kinds of literacy. The activity of communicating helps students to be able to express opinions and ideas from other scientific approaches.

Applying the scientific approach taught to students makes students more active and shows good learning outcomes, where there is a very real increase in student learning outcomes. This is because the scientific approach has the advantage of activating and improving student-learning outcomes [12].

Learning by applying a scientific approach is a way to develop the attitudes, skills and knowledge of students follow the scientific method with systematic stages. The active learning in biology learning shows that involve students actively in learning. Students describe an event, or a physical object, actively ask questions, explore knowledge, explain natural phenomena that occur around them, prove them through experimental activities, and communicate their conclusions [13].

Based on the results of survey research, the reality in the field is by what was stated by the Ministry of National Education (2008), that there are still many problems in learning biology that must be solved, such as the following: (1) students learning biology is oriented towards memorizing concepts, (2) learning biology is oriented on the test, (3) biology learning experience is not oriented to basic competencies, (4) students learning biology is limited to low-level thinking, (5) product-oriented evaluation of biology learning, and (6) students are not accustoming to developing potential thinking, which students should be properly empowered from all the potential that exists in students so that underachieving students feel valued and encouraged to be more advanced [12].

Teachers in teaching Biological concepts must emphasize the learning process and scientific attitude. The scientific process in question is a way of obtaining knowledge through observation and conducting experiments. Taken steps to strengthen the learning process by using a guided inquiry learning model based on a scientific approach through $5 \mathrm{M}$ are: observe, ask, collecting a piece of information, associate/processing information, and communicate.

The application of the scientific approach has the aim that the students can see how to actively construct concepts, laws, or principles through activity observed, formulate problems, ask hypothesis, collect data with a variety of techniques, to analyse data, make a conclusion, and communication. The scientific approach is right to give an understanding of the learner in identifying, understanding various materials using a scientific approach. The application of the scientific approach to learning involves process skills such as observing, classifying, measuring, predicting, explaining, and concluding. Characteristics of the scientific approach are student-centered learning can take science process skills in constructing concepts; law; or principles, as well as cognitive processes that have the potential to improve the development of intellect (thinking skills) and student character, where all these things work together to make students become human characters as the nation's next generation.

The scientific approach prioritizes students to gain knowledge through inquiry processes and develop thinking skills so that they can support students' creative activities in innovating or creating.

\section{CONCLUSION}

From the result and discussion, the scientific approach can be used to improve student learning outcomes in the cognitive, affective, and psychomotor domains. The results of percentage of the level of ease and difficulty in implementing the scientific approach were as follows: (1) Observing (M1) was $76.58 \%$, (2) Asking questions (M2) was $57 \%$, (3) Doing experiments (M3) was $62.6 \%$, (4) Reasoning (M4) was $30.3 \%$, and (5) Communicating (M5) was $21.5 \%$. The knowledge obtained can strengthen understanding, memory, and transfer, students feel joyful learning, because of the growing sense of investigation and success, causing students to direct their learning activities by involving their intellect and motivation, help students strengthen their self-concept because they gain the confidence to work with others. From what was initially considered difficult to do to an activity that was easy to do. Students also give various responses that are overall positive. Based on the characteristics of the answers of students, it can be assumed that students are quite familiar with what is meant by the scientific approach, what activities are contained in the scientific approach, although they still need guidance in the implementation process. There a some of the problems that arise in the study of biology such as the characteristics of students who still orientation to memorize concepts, learning process centered on the students, study biology is not oriented to basic competence, the ability of students is limited to the realm of thinking a low level, and participants not accustomed to developing the potential of 
thinking, we need a new level of innovation to create student's superior quality. The scientific approach is considered to be one right choice to address some of the problems in the biology of learning.

\section{REFERENCES}

[1] P. Ammundsen, Problem-based Learning in Biology with 20 Case Examples, Capewest, 2001. Accessed on: Sept. 2, 2020. [Online]. Available: https://capewest.ca/pbl.html

[2] A. Azizi, Implementasi Problem Based Learning (BPL) dengan Bermain Peran (BP) terhadap Kemampuan Memecahkan Masalah, JUPE: Jurnal Pendidikan Mandala 4(5) (2020) 188-194. DOI: http://dx.doi.org/10.36312/jupe.v4i5.855

[3] M, Herlina, J. Syahfitri, Ilista, Perbedaan Kemampuan Berpikir Kritis dan Hasil Belajar Kognitif dengan Model Pembelajaran Problem Based Learning Berbantuan Media Audio Visual, Edubiotik: Jurnal Pendidikan, Biologi dan Terapan 5(1) (2020) 42-54. DOI: https://doi.org/10.33503/ebio.v5i01.666

[4] D.H. Jonassen, W. Hung, Problem-based learning, in: N.M. Seel (Ed.), Encyclopedia of the Sciences of Learning, Springer, Boston, MA, 2014, pp. 485-506. DOI. https://doi.org/10.1007/978-14419-1428-6_210

[5] S. Indarti, Investigasi Implementasi Model Discovery Learning Berbasis Pendekatan Saintifik dalam Meningkatkan Aktivitas dan Hasil Belajar IPA, IJIS Edu: Indonesian Journal of Integrated Science Education 1(2) (2019) 100104.

DOI: http://dx.doi.org/10.29300/ijisedu.v1i2.2244

[6] R.P. Karl, Conjectures, Refutations: The Growth of Scientific Knowledge, Routledge, 2003.

[7] H.S. Mardiyanti, Penerapan Model Pembelajaran Problem-Based Learning untuk Meningkatkan Kemampuan Berpikir Kritis Siswa Kelas X MIPA-2, Journal of Classrom Action Research 2(1) (2020) 1-8. DOI: https://doi.org/10.29303/jcar.v2i1.395

[8] N. Nurhasanah, A.F. Hindriana, Sulistyono, Penerapan Model PBL Berbasis Outdoor Study dalam Peningkatan Keterampilan Berpikir Kritis \& Kemampuan Argumentasi Siswa, Edubiologica: Jurnal Penelitian Ilmu dan Pendidikan Biologi 8(1) (2020) 17-24. DOI: https://doi.org/10.25134/edubiologica.v8i1.2980
[9] K.N. Ratnasari, A. Syukur, Maximizing The Implementation of Scientific Approach in History Lessons through Student-Centered Learning Model, Journal of Education Research and Evaluation 4(3) (2020) 234-239. DOI: https://doi.org/10.23887/jere.v4i3.27482

[10] I. Selviani, Pengembangan Modul Biologi Problem-Based Learning untuk Meningkatkan Kemampuan Berpikir Kritis Peserta Didik SMA, IJIS Edu: Indonesian Journal of Integrated Science Education, 1(2) (2019) 147-154, DOI: https://doi.org/10.29300/ijisedu.v1i2.2032

[11] A.R. Setiawan, Efektivitas Pembelajaran Biologi Berorientasi Literasi Saintifik, Thabiea: Journal of Natural Science Teaching 2(2) (2019) 83-94. DOI: https://doi.org/10.21043/thabiea.v2i2.5345

[12] Sukini, Penerapan Pembelajaran Guided Inquiry Berbasis Pendekatan Saintifik untuk Meningkatkan Aktivitas dan Hasil Belajar Kognitif Biologi Siswa Kelas XI MIPA SMA Negeri 3 Dumai, JNSI: Journal of Natural Science and Integration 2(1) (2019) 105-121. DOI: http://dx.doi.org/10.24014/jnsi.v2i1.7118

[13] R. Susanti, Y. Anwar, Ermayanti, Implementation of learning based on scientific approach to improve science process skills of biology education students in general biology course, in: Journal of Physics: Conference Series, vol. 1166, IOP Publishing, Bristol, 2019, pp 1-5. DOI: $\quad$ https://doi.org/10.1088/1742$\underline{6596 / 1166 / 1 / 012004}$

[14] S. Suyanto, The Implementation of The Scientific Approach through 5Ms of The New Curriculum of 2013 In Indonesia, Jurnal Cakrawala Pendidikan 37(1) (2018) 22-29. DOI: https://doi.org/10.21831/cp.v37i1.18719

[15] Y.S. Syahputra, R. Santosa, S. Supriyadi, Teacher's Willingness Towards The Implementation of Scientific Approach: From Theory to Implementation, Journal of English Education 2(2) 2017 32-137. DOI: https://doi.org/10.31327/jee.v2i2.409

[16] S. Wahyuni, Implementasi Pendekatan Sainstifik Pada Pelajaran Biologi untuk Meningkatkan Hasil Belajar Kognitif dan Keterampilan Sains Siswa Kelas XI-IPA SMA Negeri 2 Lambandia, Kab. Kolaka Timur-Sultra, Jurnal Pendidikan Biologi 9(2) 2018 47-55. DOI: https://doi.org/10.17977/um052v9i2p47-55 